\title{
EFEKTIVITAS PERINGATAN KESEHATAN BERGAMBAR \\ BUNGKUS ROKOK PADA PELAJAR
}

Effectiveness of Pictural Health Warnings on Cigarette Pack Illustrated in Student

\section{*Abil Rudi **Lea Masan ***Hendrikus Nara Kwureh}

\author{
*Program Studi Perekam dan Informasi Kesehatan, STIKes Kapuas Raya Sintang \\ **Program Studi Kebidanan, STIKes Kapuas Raya Sintang \\ ***Program Studi Kesehatan Masyarakat, STIKes Kapuas Raya Sintang
}

\begin{abstract}
Abstrak
Merokok merupakan suatu masalah besar di masyarakat indonesia bahkan dunia. Merokok dapat menyebabkan banyak masalah kesehatan pada akhirnya akan berujung pada kematian. Kejadian perokok pada kelompok umur 10-14 tahun mengalami kenaikan dari 10,5\% menjadi 17,\% tahun 2011. Penelitian ini bertujuan untuk menjelaskan efektifitas peringatan kesehatan bergambar pada pelajar di SMPN 01 Badau Kabupaten Kapuas Hulu tahun 2016. Penelitian ini merupakan penelitian kuantitatif dengan rancangan cross sectional. Sampel penelitian ini menggunakan total sampling yaitu sebanyak 138 responden. Pengumpulan data dengan cara wawancara dan pengamatan yang berpedoman pada kuesioner. Analisis data mengunakan analisis univariat dan bivariat. Hasil uji statistik menunjukkan bahwa variabel yang berhubungan dengan kebiasaan merokok adalah persepsi terhadap peringatan kesehatan bergambar $(\mathrm{P}$ value $=0.011)$, penegetahuan responden $(\mathrm{P}$ value $=0.012)$, pengaruh teman $(\mathrm{P}$ value $=0.012)$ dan pengaruh orang tua $(\mathrm{P}$ value $=0.025)$. Oleh karena itu, disarankan kepada pelajar SMPN 01 Badau untuk berhenti merokok dan tidak merokok.
\end{abstract}

Kata Kunci : Merokok, peringatan kesehatan gambar di rokok, pengaruh teman dan orang tua

\begin{abstract}
Smoking is a major problem in Indonesia and even the world community. Smoking can cause many health problems will eventually lead to death. The incidence of smokers in the age group 10-14 years increased from $10.5 \%$ to $17 \%$ in 2011 . This study aims to explain the effectiveness of pictorial health warnings on students at SMPN 01 Badau Kapuas Hulu 2016. This study is a quantitative research with cross sectional design. The research sample using a total sampling as many as 138 respondents. The collection of data by means of interviews and observations are based on the questionnaire. Data analysis using univariate and bivariate analysis. Statistical analysis showed that the variables associated with smoking is the perception of the pictorial health warnings ( $\mathrm{P}$ value $=0.011)$, knowledge of respondents responden $(\mathrm{P}$ value $=0.012)$, the influence of friends $(\mathrm{P}$ value $=0.012)$ and the influence of parents ( $\mathrm{P}$ value $=0.025)$. Therefore, it is suggested to the students of SMPN 01 Badau to quit smoking and not smoking.
\end{abstract}

Keywords : Smoking, health warning images on cigarettes, the influence of friends and parents

\section{A. Pendahuluan}

Merokok sudah menjadi salah satu masalah besar di Indonesia bahkan di dunia. Merokok dapat menyebabkan banyak masalah kesehatan yang pada akhirnya akan berujung pada kematian. Penyakit tersebut seperti kanker pada paru, esofagus, laring, mulut, dan tenggorokan; penyakit kronik paru, emfisema dan bronkitis; stroke, serangan jantung, penyakit kardiovaskuler lainnya, dan masih banyak lagi (WHO, 2006).

Data WHO dalam World no Tobacco Day 2006 memperkirakan bahwa jumlah perokok diseluruh dunia adalah 1,3 milyar dengan jumlah kematian berkisar 5 juta pertahun, bila pola yang terjadi tidak ditanggulangi dengan segera maka angka kematian tersebut akan menjadi dua kali lipat pada tahun 2020 yaitu mendekati angka 10 juta orang meninggal pertahun karena pengkonsumsian rokok (WHO, 2006).

Laporan TCSC-IAKMI (Tobacco Control Support Centre-Ikatan Ahli Kesehatan Masyarakat Indonesia), tahun 2005 hingga 2008 Indonesia mengalami peningkatan konsumsi rokok. Tahun 2005 Indonesia menghabiskan 214 milyar batang 
rokok, tahun 2006 meningkat menjadi 220 milyar, tahun berikutnya meningkat menjadi 238 milyar dan tahun 2008 terjadi peningkatan kembali menjadi 240 milyar batang rokok (TCSCIAKMI, 2009).

Dari hasil wawancara singkat pada 20 siswa SMPN 01 Badau, didapat bahwa 16 siswa merokok. Dari 16 siswa yang pernah merokok didapat 11 siswa yang pernah mengalami sesak nafas. Dari 16 siswa yang pernah merokok didapatkan informasi singkat bahwa ada yang beralasan mereka merokok untuk cobacoba dan mengikuti teman-teman. Ada juga yang beralasan untuk menimbulkan rasa percaya diri, rasa berani dan anak gaul. Demikian juga informasi dari kepala sekolah bahwa ada beberapa siswa dalam tahun terakhir mengalami nilai rapot sekolah yang turun akibat sering bolos karena merokok. Merokok pada siswa SMPN 01 Badau merupakan suatu masalah kesehatan pada siswa tersebut. Merokok mengakibatkan siswa mengalami penurunan prestasi belajar, putus sekolah, bahkan dapat menyebabkan tawuran antar pelajar.

\section{B. Metode}

Penelitian ini merupakan penelitian kuantitatif dengan rancangan cross sectional yaitu suatu rancangan penelitian dimana variabel independen dan variabel dependen diukur pada waktu penelitian berlangsung yang dapat menjelaskan suatu hubungan (Hidayat, 2007). Penelitian ini dilakukan pada pelar SMPN 01 Badau dari kelas I, II dan III. Jumlah sampel dalam penelitian ini adalah sebanyak 138 responden.

\section{Hasil}

\section{Hasil Analisis Univariat}

Tabel 1

Distribusi Frekuensi Berdasarkan Kebiasaan Merokok pada Siswa SMPN 01 Badau Kabupaten Kapuas Hulu 2016

\begin{tabular}{ccc}
\hline Kebiasaan Merokok & $\mathrm{n}$ & $\%$ \\
\hline Merokok & 22 & 15.9 \\
Tidak Merokok & 116 & 84.1 \\
\hline Total & 138 & 100 \\
\hline
\end{tabular}

Berdasarkan Tabel 1 didapatkan distribusi frekuensi kebiasaan merokok pada siswa SMPN 01 Badau Kabupaten Kapuas Hulu tahun 2016 yang paling tinggi dalah kebiasaan tidak merokok sebanyak 116 responden $(84,1 \%)$ dan kebiasaan merokok sebanyak 22 responden $(15,9 \%)$.

\section{Hasil Analisis Bivariat}

Tabel 2

Hubungan antara Pengetahuan, Pengaruh Teman, Pengaruh Orang Tua, Persepsi terhadap Peringatan Kesehatan Bergambar pada Rokok dengan Kebiasaan Merokok pada Siswa SMPN 01 Badau Kabupaten Kapuas Hulu Tahun 2016

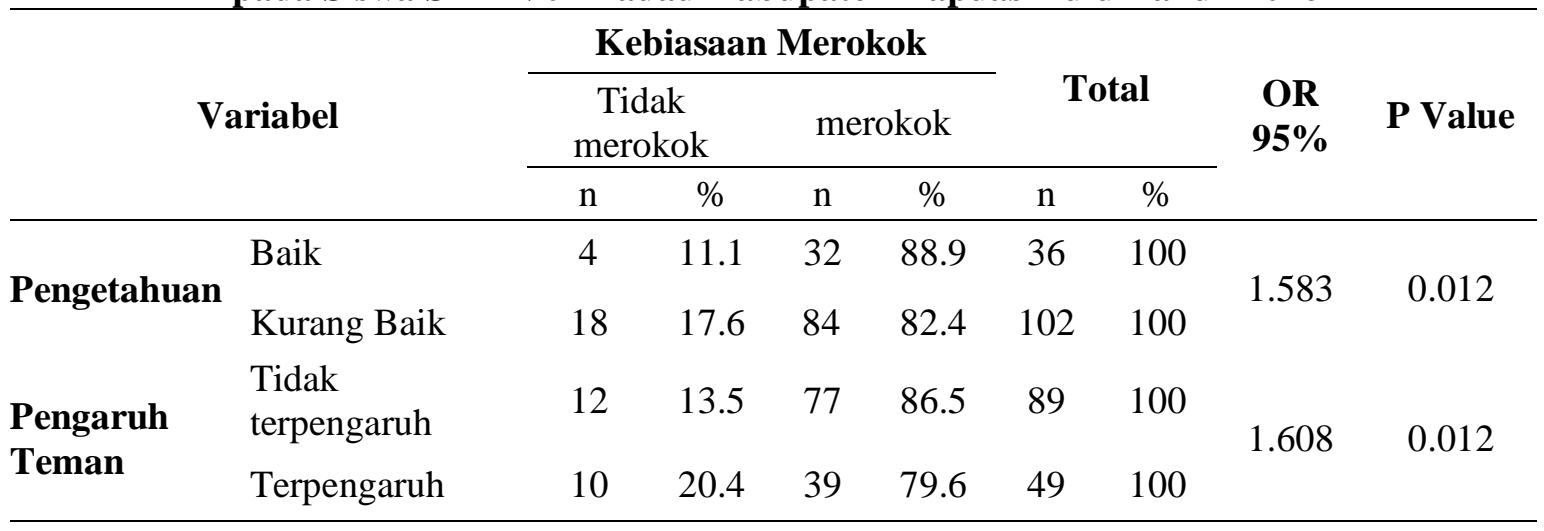




\begin{tabular}{llcccccccc}
\hline \multirow{2}{*}{$\begin{array}{l}\text { Pengaruh } \\
\text { orang tua }\end{array}$} & $\begin{array}{l}\text { Tidak } \\
\text { terpengaruh }\end{array}$ & 8 & 13.8 & 50 & 86.2 & 58 & 100 & & \\
& Terpengaruh & 14 & 17.5 & 66 & 82.5 & 80 & 100 & & \\
& Baik & 7 & 8.6 & 74 & 91.4 & 81 & 100 & & \\
Persepsi & Kurang Baik & 15 & 26.3 & 42 & 73.7 & 57 & 100 & & 0.025 \\
& & & & & & & & & \\
\hline
\end{tabular}

Berdasarkan tabel 2 dapat dilihat bahwa kebiasaan merokok pada responden dengan pengetahuan baik sebanyak 4 responden $(11.1 \%)$ dan pengetahuan kurang baik sebanyak 18 responden (17.6\%). Hasil uji statistik diperoleh $\mathrm{P}_{\text {value }}=0.012 \leq 0.05$, artinya ada hubungan antara pengetahuan responden dengan kebiasaan merokok di SMPN 01 Badau Kabupaten Kapuas Hulu Tahun 2016. Dari hasil analisis diperoleh juga nilai $\mathrm{OR}=1.583$, artinya pengetahuan responden kurang baik mempunyai faktor risiko sebesar 1.5 dibandingkan responden berpengetahuan baik dengan kebiasaan merokok.

Terpengaruh oleh teman dengan kebiasaan merokok sebanyak 39 responden $(79,6 \%)$ dan terpengaruh teman dengan kebiasaan tidak merokok sebanyak 10 responden $(20,4 \%)$. Hasil uji statistik diperoleh $\mathrm{P}_{\text {value }}=0.012 \leq 0.05$, artinya ada hubungan antara pengaruh teman dengan kebiasaan merokok di SMPN 01 Badau Kabupaten Kapuas Hulu Tahun 2016. Dari hasil analisis diperoleh juga nilai $\mathrm{OR}=$ 1.608, artinya pengaruh teman yang merokok mempunyai faktor risiko sebesar 1.6 kali meningkat dibandingkan dengan pengaruh teman yang tidak merokok.

\section{Pembahasan}

\section{Hubungan pengetahuan responden dengan kebiasaan merokok}

Hasil uji statistik diperoleh $P_{\text {value }}=0.012 \leq 0.05$, artinya ada hubungan antara pengetahuan responden dengan kebiasaan merokok di SMPN 01 Badau Kabupaten Kapuas Hulu Tahun 2016.

Hasil penelitian ini menemukan bahwa pengetahuan yang baik proporsinya lebih rendah di bandingkan pengetahuan kurang baik tentang merokok. Hal ini di dasari bahwa rata-rata siswa SMPN 01 Badau Memiliki pengetahun yang kurang tentang bahaya merokok, karena
Terpengaruh oleh orang tua dengan kebiasaan merokok sebanyak 66 responden $(82,5 \%)$ dan terpengaruh orang tua dengan kebiasaan tidak merokok sebanyak 14 responden $(17,5 \%)$. Hasil uji statistik diperoleh $\mathrm{P}_{\text {value }}=0.025 \leq 0.05$, artinya ada hubungan antara pengaruh orang tua dengan kebiasaan merokok di SMPN 01 Badau Kabupaten Kapuas Hulu Tahun 2016. Dari hasil analisis diperoleh juga nilai $\mathrm{OR}=2.754$, artinya pengaruh orang tua merokok mempunyai faktor risiko sebesar 2.7 kali meningkat dibandingkan dengan pengaruh orang tua yang tidak merokok.

Persepsi kurang baik dengan kebiasaan merokok sebanyak 42 responden $(73.7 \%)$ dan persepsi baik dengan kebiasaan merokok sebanyak 15 responden $(26.3 \%)$. Hasil uji statistik diperoleh $\mathrm{P}_{\text {value }}=0.011 \leq 0.05$, artinya ada hubungan antara persepsi responden dengan kebiasaan merokok di SMPN 01 Badau Kabupaten Kapuas Hulu Tahun 2016. Dari hasil analisis diperoleh juga nilai $\mathrm{OR}=2.754$, artinya persepsi kurang baik terhadap kesehatan bergambar pada rokok mempunyai faktor risiko sebesar 1.2 kali meningkat dibandingkan dengan persepsi baik terhadap kesehatan bergambar pada rokok.

kebanyakan siswa yang sekolah di SMPN 01 Badau berasal dari kampung di daerah kecamatan Badau yang dimana tertinggal dalam mengakses

informasi termasuk tentang bahaya merokok.

Soekidjo Notoatmojo (2010) mengemukakan bahwa pengetahuan adalah hasil pengindera manusia atau hasil tahu seseorang terhadap objek melalui indera yang dimilikinya. Seseorang dapat meningkatkan pengetahuan kesehatan jika mendapatkan informasi yang baik. Dapat disimpulkan bahwa sebagian besar 
responden memiliki kemudahan akses untuk memperoleh informasi tentang rokok sehingga mereka memiliki pengetahuan yang baik tentang rokok.

Hal ini sejalan dengan penelitian Barus (2012) yang menganalisis hubungan antara pengetahuan tentang rokok dengan motivasi berhenti merokok ditemukan nilai $\mathrm{P}_{\text {value }}$ sebesar 0,045 yang berarti ada hubungan yang bermakna secara statistik antara pengetahuan tentang rokok dengan motivasi berhenti merokok.

\section{Hubungan pengaruh teman dengan kebiasaan merokok}

Hasil uji statistik diperoleh $P_{\text {value }}=0.012 \leq 0.05$, artinya ada hubungan antara pengaruh teman dengan kebiasaan merokok di SMPN 01 Badau Kabupaten Kapuas Hulu Tahun 2016.

Hasil penelitian ini menemukan bahwa pengaruh teman lebih sedikit dibandingkan tidak terpengaruh oleh teman dengan kebiasaan merokok. Hal ini di dasari bahwa rata-rata siswa SMPN 01 Badau memiliki teman dengan berpengetahuan yang kurang tentang bahaya merokok, karena kebanyakan siswa yang sekolah di SMPN 01 Badau berasal dari kampung di daerah kecamatan Badau yang dimana tertinggal dalam mengakses informasi termasuk tentang bahaya merokok. Selain itu juga, bahwa siswa SMPN 01 Badau terpapar oleh rokok sejak mereka dari sekolah dasar.

Selain itu juga bahwa, semakin banyak teman-teman yang sudah merokok maka semakin besar kemungkinan akan merokok. Munculnya perilaku dari organisme ini dipengaruhi oleh faktor stimulus yang diterima, baik stimulus internal maupun stimulus eksternal. Seperti halnya perilaku lain, perilaku merokok akan muncul karena adanya faktor internal (faktor biologis dan faktor psikologis, seperti perilaku merokok dilakukan untuk mengurangi stres) dan faktor eksternal (faktor lingkungan sosial, seperti terpengaruh oleh teman sebaya).

\section{Hubungan pengaruh orang tua dengan kebiasaan merokok \\ Hasil uji statistik diperoleh $\mathrm{P}_{\text {value }}=0.025 \leq 0.05$, artinya ada hubungan}

Dengan diberlakukannya peringatan kesehatan bergambar pada kemasan rokok di Indonesia yang terdiri dari 5 gambar berbeda, diharapkan dapat meningkatkan pengetahuan perokok akan bahaya rokok sehingga menimbulkan motivasi untuk berhenti merokok. Pada tahun 2001, setelah PHW mulai diberlakukan di Kanada, sehingga jumlah konsumsi rokok menurun drastis ke level terendah dalam 36 tahun terakhir, dan terus menerus berkurang sejak saat itu (Shields dkk, 2007).

Perilaku merokok adalah aktivitas seseorang yang merupakan respons orang tersebut terhadap rangsangan dari luar yaitu faktor-faktor yang mempengaruhi seseorang untuk merokok dan dapat diamati secara langsung. Sedangkan menurut Istiqomah (2010) merokok adalah membakar tembakau kemudian dihisap, baik menggunakan rokok maupun menggunakan pipa.Temparatur sebatang rokok yang tengah dibakar adalah 90 derajat Celcius untuk ujung rokok yang dibakar, dan 30 derajat Celcius untuk ujung rokok yang terselip diantara bibir perokok (Istiqomah, 2009).

Sari dkk (2003) menyebutkan bahwa perilaku merokok adalah aktivitas menghisap atau menghirup asap rokok dengan menggunakan pipa atau rokok. Menurut Ogawa (Triyanti, 2008) dahulu perilaku merokok disebut sebagai suatu kebiasaan atau ketagihan, tetapi dewasa ini merokok disebut sebagai tobacco dependency sendiri dapat didefinisikan sebagai perilaku penggunaan tembakau yang menetap, biasanya lebih dari setengah bungkus rokok per hari, dengan adanya tambahan distres yang disebabkan oleh kebutuhan akan tembakau secara berulang-ulang. Perilaku merokok dapat juga didefinisikan sebagai aktivitas subjek yang berhubungan dengan perilaku merokoknya, yang diukur melalui intensitas merokok, waktu merokok, dan fungsi merokok dalam kehidupan seharihari (Komalasari, dkk, 2000).

antara pengaruh orang tua dengan kebiasaan merokok di SMPN 01 Badau Kabupaten Kapuas Hulu Tahun 2016. 
Hasil penelitian ini menemukan bahwa terpengaruh orang tua yang merokok lebih banyak dibandingkan dengan orang tua yang tidak merokok. Hal ini didasari karena melihat orang tua merokok maka ingin mencoba untuk merokok dengan alasan ingin tahu atau hanya ingin mencoba-coba merokok. Namun, rasa ingin tahu atau mencoba-coba rokok justru mengarahkan kebiasaan ingin terus menerus untuk merokok.

Perilaku merokok adalah aktivitas seseorang yang merupakan respons orang tersebut terhadap rangsangan dari luar yaitu faktor-faktor yang mempengaruhi seseorang untuk merokok dan dapat diamati secara langsung. Sedangkan menurut Istiqomah (2010) merokok adalah membakar tembakau kemudian dihisap, baik menggunakan rokok maupun menggunakan pipa. Temparatur sebatang rokok yang tengah dibakar adalah 90 derajat Celcius untuk ujung rokok yang dibakar, dan 30 derajat Celcius untuk ujung rokok yang terselip di antara bibir perokok (Istiqomah, 2009).

\section{Persepsi terhadap peringatan kesehatan bergambar pada rokok dengan kebiasaan merokok}

Hasil uji statistik diperoleh $\mathrm{P}_{\text {value }}=0.011 \leq 0.05$, artinya ada hubungan antara persepsi responden dengan kebiasaan merokok di SMPN 01 Badau Kabupaten Kapuas Hulu Tahun 2016.

Hasil penelitian ini menggambarkan bahwa secara umum kesadaran pelajar akan dampak buruk merokok sudah tinggi. Berbagai strategi penyampaian informasi peringatan kesehatan dampak buruk rokok sudah dilakukan, salah satunya dengan mencantumkan label bergambar penyakit akibat rokok pada kemasan rokok. Bahkan, ada responden yang menganggap bahwa label peringatan kesehatan pada kemasan rokok belum efektif dalam memberikan informasi bahaya rokok bagi kesehatan, namun faktanya masih banyak responden yang tidak mengabaikan pesan kesehatan yang tertera pada label tersebut dan tidak melanjutkan aktifitas merokoknya. Persepsi adalah inti komunikasi, sedangkan penafsiran

\section{E. Kesimpulan}

Berdasarkan hasil penelitian pada siswa SMPN 01 Badau Kabupaten Kapuas
Sari dkk (2003) menyebutkan bahwa perilaku merokok adalah aktivitas menghisap atau menghirup asap rokok dengan menggunakan pipa atau rokok. Menurut Ogawa (Triyanti, 2008) dahulu perilaku merokok disebut sebagai suatu kebiasaan atau ketagihan, tetapi dewasa ini merokok disebut sebagai tobacco dependency sendiri dapat didefinisikan sebagai perilaku penggunaan tembakau yang menetap, biasanya lebih dari setengah bungkus rokok per hari, dengan adanya tambahan distres yang disebabkan oleh kebutuhan akan tembakau secara berulangulang. Perilaku merokok dapat juga didefinisikan sebagai aktivitas subjek yang berhubungan dengan perilaku merokoknya, yang diukur melalui intensitas merokok, waktu merokok, dan fungsi merokok dalam kehidupan sehari-hari (Komalasari, dkk, 2000).

(interpretasi) adalah inti persepsi, yang identik dengan penyandian-balik (decoding) dalam proses komunikasi (Mulyana, 2008). Dalam Peraturan Pemerintah Indonesia Nomor 109 Tahun 2012 tentang pengamanan bahan yang mengandung zat adiktif berupa produk tembakau bagi kesehatan menyebutkan, Peringatan Bergambar Bungkus Rokok adalah setiap keterangan mengenai rokok yang berbentuk gambar, tulisan, kombinasi keduanya, atau bentuk lain yang disertakan pada rokok, dimasukkan ke dalam, ditempatkan pada, atau merupakan bagian kemasan rokok.

Hasil penelitian ini sejalan dengan penelitian yang dilakukan oleh Darojah (2014) menunjukkan bahwa berdasarkan uji chi-square diperoleh nilai $\mathrm{P}_{\text {value }}=0,045$ yang berarti bahwa ada hubungan antara persepsi terhadap label gambar peringatan kesehatan pada kemasan rokok dengan penghambat berhenti merokok pada kepala keluarga di Kecamatan Jatiyoso Kabupaten Karanganyar.

Hulu Tahun 2016, dapat diambil kesimpulan bahwa variabel yang berhubungan dengan 
kebiasaan merokok adalah pengetahuan $\left(\mathrm{P}_{\text {value }}=0.012\right)$, pengaruh teman $\left(\mathrm{P}_{\text {value }}=0.012\right)$, pengaruh orang tua $\left(\mathrm{P}_{\text {value }}=0.025\right)$ dan persepsi $\left(\mathrm{P}_{\text {value }}=0.011\right)$. Oleh karena itu, di sarankan kepada siswa untuk tidak mengkonsumsi rokok sejak dini, bagi orang

\section{Daftar Pustaka}

Barus, H., 2012. Hubungan Pengetahuan Perokok Aktif Tentang Rokok Dengan Motivasi Berhenti Merokok Pada Mahasiswa FKM dan FISIP Universitas Indonesia. Fakultas Ilmu Keperawatan, Universitas Indonesia, Depok (Skripsi).

Darojah, S., 2014. Faktor Determinan Penghambat Berhenti Merokok Pada Kepala Keluarga Di Kecamatan Jatiyoso Kabupaten Karanganyar (Doctoral dissertation, Universitas Muhammadiyah Surakarta).

Frayling, T.M., Timpson, N.J., Weedon, M.N., Zeggini, E., Freathy, R.M., Lindgren, C.M., Perry, J.R., Elliott, K.S., Lango, H., Rayner, N.W. and Shields, B., 2007. A common variant in the FTO gene is associated with body mass index and predisposes to childhood and adult obesity. Science, 316 (5826), pp.889-894.

Hidayat, A.A. 2007. Metode Penelitian Keperawatan dan Teknik Analisa Data. Jakarta : Salemba medika

Istiqomah, D.F., 2010. Analisis Pengaruh Profitabilitas, Solvabilitas, Likuiditas, Dan Kepemilikan Publik Terhadap Keterlambatan Publikasi Laporan Keuangan Studi Empiris pada Perusahaan Nonmanufaktur yang Terdaftar di Bursa (Doctoral dissertation, UNIVERSITAS SEBELAS MARET).

Istiqomah, L., Sofyan, A., Damayanti, E. and Julendra, H., 2009. Amino acid profile of earthworm and earthworm meal (Lumbricus rubellus) for animal tua siswa untuk tidak merokok di depan anaknya atau berhenti merokok dan bagi pihak sekolah di harapkan untuk dapat menempelkan poster tentang bahaya merokok di lingkungan soklah seperti di mading sekolah serta di dalam kelas.

feedstuff. Journal of the Indonesian Tropical Animal Agriculture,34(4), pp.253-257.

Komalasari, Dian \& Helmi, Avin Fadilla. 2000. Faktor-Faktor Penyebab Perilaku Merokok Pada Remaja. Jurnal Psikologi, 28: 37-47.

Mulyana, Deddy. 2008. Ilmu Komunikasi : Suatu Pengantar, Jakarta : PT. Remaja Rosdakarya.

Notoatmodjo, S. 2010. Metodologi Penelitian Kesehatan. Jakarta : Rineka Cipta

Sari, A.T.O., Ramdhani, N. and Eliza, M., 2003. Empati dan perilaku merokok di tempat umum. Jurnal Psikologi,30(2), pp.81-90.

TCSC-IAKMI. 2009. Fakta Tembakau "Permasalahannya di Indonesia Tahun 2009".

http://www.indofbh.org/tcscindo/assets/app lets/Buku_Profil_Kesehatan_Final_Revisi_ vhie.pdf

Triyanti. 2008. Kebiasaan Merokok. http://triyanti.blogspot.com/2007/07/-

kebiasaan-merokok.html. Diakses pada tanggal 29 April 2016, pukul 11.10 WIB.

WHO. 2006. World No Tobacco Day 2006. www.WHO.int/tobacco/wntd/2006/en/inde x.html

WHO. 2008. WHO Report on Global Tobacco Epidemic, 2008. http://www.WHO.int/tobacco/mpower/gtcr _download/en/index.html 